\title{
IMPLEMENTASI STRATEGI PEMASARAN DALAM MENINGKATKAN JUMLAH PENJUALAN PRODUK- PRODUK USAHA KECIL BINAAN POLITEKNIK NEGERI BALIKPAPAN
}

\author{
\#1Ida Suriana, ${ }^{* 2}$ Hasto Finanto, ${ }^{\# 3}$ Asri Setiarini, \#4Saiful Ghozi, \#5Totok Ismawanto \\ $\# 1,2,3,4,5$ Program Studi Perbankan dan Keuangan, , Politeknik Negeri Balikpapan \\ Jl. Soekarno Hatta Km 8, Balikpapan \\ 1ida.suriana@poltekba.ac.id \\ 2hasto.finanto@poltekba.ac.id \\ 3asri.setiarini@poltekba.ac.id \\ ${ }^{4}$ saiful.ghozi@poltekba.ac.id \\ 5totok.ismawanto@poltekba.ac.id
}

\begin{abstract}
ABSTRAK
Pengelolan buah naga menjadi produk-produk yang khas dan memberikan manfaat secara ekonomi bagi masyarakat yang tergabung dalam kelompok tani warga Karang Joang RT 19 KM 12 Balikpapan utara sudah cukup lama namun kelompok ini masih belum memiliki pengetahuan yang baik tentang bagaimana memasarkan produk yang mereka hasilkan dengan tepat sehingga mereka dapat mengenalkan produk mereka kepada masyarakat dan meningkatkan penjualan produknya. Berdasarkan hasil observasi permasalahan mitra pada kelompok tani warna Karang Joang RT 19 dapat diidentifikasi sebagai berikut: 1) Bagaimana memasarkan produk agar lebih dikenal oleh masyarakat luas baik melalui media offline maupun menggunakan media sosial, 2) Bagaimana desain produk agar masyarakat mengenal hasil olahan buah naga. Solusi yang ditawarkan berdasarkan uraian permasalahan mitra yang sedang dihadap diantaranya yaitu: 1) Pembekalan pengetahuan dasar tentang pemasaran, 2) pendampingan pemasaran baik secara offline mau menggunakan media sosial.
\end{abstract}

Keywords - peningkatan penjualan dan strategi pemasaran

\section{PENDAHULUAN}

Usaha Mikro Kecil dan Menengah (UMKM) dan Koperasi memiliki peranan penting dalam perekonomian Indonesia sangatlah besar. Salah satunya adalah menyediakan lapangan pekerjaan dan meghasilkan output untuk menjalankan perekonomian baik skala lokal maupun skala nasional. Pemberdayaan UMKM dan Koperasi menjadi salah satu strategi untuk dapat meningkatkan taraf hidup sebagian besar rakyat Indonesia. Pemberdayaan UMKM dan Koperasi ini dapat mendukung upaya pemerintah dalam menekan angka kemiskinan di Indonesia.

Usaha Kecil menurut Undang-Undang No,.9 tahun 1995 adalah usaha produktif yang berskala kecil dan memenuhi kriteria kekayaan bersih paling banyak Rp.200.000.000,00 (dua ratus juta rupiah) tidak termasuk tanah dan bangunan tempat usaha atau memiliki hasil penjualan paling banyak Rp.1.000.000.000,00 (satu milyar rupiah) per tahun serta dapat menerima kredit dari bank maksimal di atas Rp.50.000.000,00 (lima puluh juta rupiah) sampai $\mathrm{Rp}$ $500.000 .000,00$ (lima ratus juta rupiah).

Kota Balikpapan dipandang sebagai kota yang amat potensial untuk mengembangkan usaha kecil. Oleh karena itu pengembangan usaha kecil di kota Balikpapan dilakukan secara optimal, tidak saja semata-mata bertujuan mendapatkan penghargaan tetapi yang lebih penting dari itu juga bertujuan agar 
pengembangan usaha kecil dapat memiliki kontribusi signifikan terhadap efektifitas upaya meningkatkan kesejahteraan masyarakatnya.

Walaupun usaha kecil memiliki peranan yang amat penting namun mengalami beberapa kendala dalam menjalakan dan mengembangkan usaha yang sangat potensial. Salah satu kendalanya yang dihadapi oleh usaha kecil di Balikpapan adalah pengenalan masyarakat terhadap produk UMKM masih rendah. Hal ini dapat dilihat dari Laporan Akuntabilitas Kinerja Instansi Pemerintah Tahun 2015 yang dikeluarkan oleh Dinas Perindustrian dan Koperasi. Oleh karena itu sangatlah penting pembinaan usaha kecil agar dapat mengenalkan produk yang dihasilkan dan dapat meningkatkan penjualan produk.

- Dari segi pemasaran produk pun usaha kecil mengalami beberapa kendala terutama usaha kecil yang dikelola oleh ibu-ibu rumah tangga yang kurang paham teknologi. Sehingga menyulitkan mereka untuk melakukan pemasaran yang menjadi tren saat ini.

\section{PERMASALAHAN MITRA}

Berdasarkan pembahasan dan hasil observasi, maka permasalahan mitra dapat diidentifikasi sebagai berikut:

1. Bagaimana memanfaatkan teknologi informasi dan media sosial untuk meningkatkan penjualan produk?

2. Bagaimana membuat kemasan menarik sehingga produk lebih dikenal oleh masyarakat?

3. Dari beberapa varian produk, produk apa saja yang disukai oleh konsumen?

\section{TARGET DAN LUARAN}

Berdasarkan uraian permasalahan mitra di atas dapat ditentukan solusi dan sekaligus metode kegiatan yaitu "

Implementasi Strategi Pemasaran Dalam Meningkatkan Jumlah Penjualan ProdukProduk Usaha Kecil Binaan Politeknik Negeri Balikpapan" dalam menjawab permasalahan yang sedang dihadapi oleh mitra, yaitu diantaranya:

1. Pelatihan strategi pemasaran dalam meningkatkan jumlah penjulan.

2. Pendampingan menggunakan media sosial dalam memperkenalkan produk.

3. Pendampingan pembuatan kemasan yang menarik.

\section{METODE PELAKSANAAN}

Pelaksanaan dari kegiatan pengabdian masyarakat tentang "Pengembangan Variasi Produk Olahan Buah Naga menjadi Produk pangan dalam meningkatkan Kesejahteraan Petani Karang Joang Balikpapan" dengan tahapan sebagai berikut:

1. Tahap pertama yaitu Survey Pada tahap ini dilakukan pendataan

2. Tahap Kedua yaitu Sosialisasi program pelatihan

Pada tahap ini yaitu memberikan informasi yang jelas kepada peserta pelatihan terhdap program pelatihan yang akan dilaksanakan

3. Tahap ke tiga yaitu Procurement (pengadaan alat dan barang)

Pada tahap ini melakukan pengadaan barang yang tepat dan sesuai dengan kebutuhan. Dengan mencari harga yang tepat dan cocok dan sesuai serta transparant dalam mendukung kegiatan pengabdian masyarakat ini.

4. Tahap ke empat yaitu Pelaksanaan Pelatihan

Pada tahap ini merupakan kegiatan ini dari program pelatihan yang terdiri kegiatan teori dan praktik. Kegiatan ini dilakukan selama 2 hari, pada hari 1 untuk kegiatan teori dan hari ke 2 untuk kegiatan praktik. Kegiatan praktik di laksanakan di ruang praktik (kitchen) Prodi Tata Boga Politeknik Negeri Balikpapan.

5. Tahap ke lima yaitu Pendampingan Pada tahap ini diberikan pendampingan secara berkelanjutan dan sistematis, untuk memastikan kualitas produk yang dihasilkan dan layak dipasarkan. Kegiatan pendampingan ini akan dilaksanakan beberapa bulan pasca pelatihan. 


\section{HASIL DAN PEMBAHASAN}

Sesuai dengan target luaran yang akan dihasilkan di dalam pelatihan Implementasi Strategi Pemasaran Dalam Meningkatkan Jumlah Penjualan Produk-Produk Usaha Kecil Binaan Politeknik Negeri Balikpapan maka kegiatan yang dilakukan adalah:

1. Kegiatan survei untuk melakukan studi kelayakan potensi lokal buah naga yang dapat diolah menjadi permen dan selai. Selain itu mengenai peserta yang akan dilibatkan dalam kegiatan ini.

\section{Sosialisasi}

Pelaksanaan sosialisasi ini diberikan untuk memberikan informasi yang lebih jelas terhadap program pengabdian yang akan diselenggarakan, berikut ini kegiatan yang terdapat di dalam program tersebut dan rencana pelaksanaan. Tujuan dari sosialisasi ini antara lain:

a. Untuk memberikan informasi dan gambaran kepada kelompok masyarakat khususnya calon penerima manfaat dan aparat RT, tentang kelanjutan kegiatan seperti yang sudah pernah dilakukan sebelumnya.

b. Memberikan motivasi kembali kepada anggota kelompok yang mungkin sudah berkurang keaktifannya sehingga dapat lebih bersungguh-sungguh dalam mengelola usaha. Melakukan kesepakatan mengenai rencana pelaksanaan kegiatan penyuluhan, pelatihan dan pendampingan

\section{Pengadaan Bahan Peralatan}

Pengadaan bahan dan peralatan dilakukan untuk memenuhi kebutuhan bahan dan peralatan disesuaikan dengan jumlah kelompok dari peserta. Selain itu diadakan sesuai dengan aspek yang dibutuhkan, harga yang sesuai dalam mendukung kegiatan pengabdian tersebut. Bahan dan peralatan digunakan pada saat pelatihan dan setelah kegiatan selesai peralatan dan sisa bahan dihibahkan dengan peserta sebagai investasi dan modal usaha yang akan dikembangkan.

4.Pelaksanaan Pelatihan

Kegiatan ini dimulai dengan pemberian teori tentang dasar-dasar pemasaran dan praktik penggunaan media sosial instagram dalam melaksanakan penjualan dan mengenalkan produk. Dan pelatihan pembutan kemasan yang menarik.

5. Kegiatan ini dilakukan secara berkelanjutan dan sistematis. Pendampingan kemudian dilanjutkan dengan survei kepada konsumen untuk melihat dari 5 varian produk yang ada, produk mana yang paling disukai sehingga dapat memfokuskan pada beberapa produk yang memang benar-benar diinginkan oleh konsumen. Berikut table hasil survei yang telah dilakukan

TABEL I

HASIL SURVEI KONSUMEN

\begin{tabular}{|l|c|c|c|}
\hline \multirow{2}{*}{ Produk } & \multicolumn{3}{|c|}{ HASIL SURVEI } \\
\cline { 2 - 4 } & SUKA & NETRAL & $\begin{array}{c}\text { TIDAK } \\
\text { SUKA }\end{array}$ \\
\hline $\begin{array}{l}\text { Cimi-cimi } \\
\text { Buah Naga }\end{array}$ & 50 & 0 & 0 \\
\hline $\begin{array}{l}\text { Permen } \\
\text { Buah Naga }\end{array}$ & 40 & 10 & 0 \\
\hline $\begin{array}{l}\text { Dodol Buah } \\
\text { Naga }\end{array}$ & 47 & 3 & 0 \\
\hline $\begin{array}{l}\text { Selai Buah } \\
\text { Naga }\end{array}$ & 20 & 20 & 10 \\
\hline $\begin{array}{l}\text { Mie Buah } \\
\text { Naga }\end{array}$ & 5 & 40 & 5 \\
\hline
\end{tabular}

Dari 50 orang responden yang diberikan 5 jenis produk yang sudah di produksi. Produk yang paling disukai adalah cimi-cimi buah naga dan dodol buah naga. Hasil Survei ini memberikan gambaran kepada usaha kecil ini untuk memfokukskan pada beberap produk dan melakukan evaluasi kepada produk yang tidak disukai sesuai dengan masukan yang diberikan oleh konsumen.

TABEL III

HaSil PENJUALAN PRODUK SELAMa DilaKSANAKAN PENDAMPINGAN

\begin{tabular}{|l|c|}
\hline \multicolumn{1}{|c|}{ BULAN } & $\begin{array}{c}\text { JUMLAH } \\
\text { PENJUALAN }\end{array}$ \\
\hline April & 30 pack \\
\hline Mei & 32 pack \\
\hline Juni & 35 pack \\
\hline Juli & 35 pack \\
\hline Agustus & 40 pack \\
\hline September & 45 pack \\
\hline Oktober & 42 pack \\
\hline November & 150 pack \\
\hline
\end{tabular}




\section{KESIMPULAN}

Berdasarkan hasil pelaksanaan kegiatan program Pengabdian Masyarakat dapat disimpulkan bahwa:

1. Program pengabdian masyarakat ini memberikan dampak terhadap pengetahuan dan peningkatan penjualan produk serta kemampuan untuk menggunakan media social dalam memasarkan prdoduk.

2. Menyediakan bantuan alat pengolahan dan kemasan untuk produk yang sudah dihasilkan.

3. Secara keseluruhan kegiatan pengabdian masyarakat dari perguruan tinggi sangat diharapkan oleh masyarakat dalam mengimplementasikan ilmu dan hasil penelitian ditengah-tengah masyarakat.

Berdasarkan hasil pelaksanaan kegiatan program Pengabdian Masyarakat ada beberapa saran yang menjadi perhatian yaitu:

1. Koordinasi dan komunikasi yang efektif pada semua stake holder pelatihan baik dengan masyarakat maupun dengan tim pelaksana serta partner lain yang terlibat mutlak diperlukan sehingga dapat bersinergi dengan baik dalam mencapai tujuan program ini.

2. Gagasan/ ide ide serta saran saran yang muncul dari bawah (warga) hendaknya diperhatikan dan ditindaklanjuti dengan baik melihat besarnya minat warga untuk dapat mengembangkan usaha di bidang pengolahan makanan ini.

\section{UCAPAN TERIMA KASIH}

Ucapan terimakasih kami berikan kepada Direktur Politeknik Negeri Balikpapan yang senantiasa memberikan dukungan dalam melaksanakan kegiatan pengabdian kepada masyarakat ini serta ketua RT 19 Kelurahan Karang Joang Balikpapan Serta Warga RT 19 Kelurahan Karang Joang Balikpapan dengan adanya dukungan dari semua pihak yang telah membantu sehingga kegiatan ini dapat berlangsung dengan baik.

\section{DAFTAR PUSTAKA}

Herudiyanto, M.S., 2008. Teknologi pengemasan pangan. Bandung: Widya Padjadjaran.

Kotler, P. and Keller, K.L., 2009. Manajemen pemasaran jilid 1. Jakarta: PT. Prehallindo.

Kotler, P. and Keller, K.L., 2009. Manajemen pemasaran. Jakarta: Erlangga, 71.

Makmur, R., 2016. Bisnis Online. Bandung: Informatika.

Rizaldi, T. and Hermawan, H., 2017. Pemanfaatan E-Commerce sebagai Strategi Peningkatan Pemasaran UMKM. Prosiding. 